Prime Minister, Cabinet and Core Executive 


\section{Prime Minister, Cabinet and Core Executive}

Edited by

R. A.W. Rhodes

and

Patrick Dunleavy 
Editorial matter and selection (๑) R. A. W. Rhodes and Patrick Dunleavy 1995 Introduction ( R. A. W. Rhodes 1995; Chapter 1 @ R. A. W. Rhodes 1995; Chapter 2 @ Basil Blackwell Ltd 1993; Chapter 3 @ Simon James 1995; Chapter 4 (c) George Jones 1995; Chapter 5 @ Basil Blackwell Ltd 1994; Chapters 6, 7, 9, 10 @ Basil Blackwell 1990; Chapter 8 @ Alan Beattie 1995; Chapter 11 @ Helen Thompson 1995; Chapter 12 @ Cambridge University Press 1993, Patrick Dunleavy 1995; Chapter 13 C Patrick Dunleavy 1994, 1995

All rights reserved. No reproduction, copy or transmission of this publication may be made without written permission.

No paragraph of this publication may be reproduced, copied or transmitted save with written permission or in accordance with the provisions of the Copyright, Designs and Patents Act 1988, or under the terms of any licence permitting limited copying issued by the Copyright Licensing Agency, 90 Tottenham Court Road, London W1P 9HE.

Any person who does any unauthorised act in relation to this publication may be liable to criminal prosecution and civil claims for damages.

First published in Great Britain 1995 by

MACMILLAN PRESS LTD

Houndmills, Basingstoke, Hampshire RG21 2XS

and London

Companies and representatives

throughout the world

A catalogue record for this book is available from the British Library.

ISBN 978-0-333-55528-6 ISBN 978-1-349-24141-5 (eBook)

DOI 10.1007/978-1-349-24141-5

$\begin{array}{lrrrrrrrr}10 & 9 & 8 & 7 & 6 & 5 & 4 & 3 & 2\end{array}$

$\begin{array}{lllll}05 & 04 & 03 & 02 & 01\end{array}$

First published in the United States of America 1995 by

Scholarly and Reference Division,

ST. MARTIN'S PRESS, INC.,

175 Fifth Avenue,

New York, N.Y. 10010

ISBN 978-0-312-12616-2

Library of Congress Cataloging-in-Publication Data

Prime minister, cabinet and core executive / edited by R. A. W. Rhodes and Patrick Dunleavy.

p. $\mathbf{c m}$.

Includes bibliographical references and index.

ISBN 978-0-312-12616-2

1. Prime ministers-Great Britain. 2. Cabinet system-Great

Britain. I. Rhodes, R. A. W. II. Dunleavy, Patrick.

JN405.P75 1995

354.4103' 13-dc20 


\section{Contents}

List of Tables

vii

List of Figures

viii

Notes on the Contributors

ix

Introducing the Core Executive

R.A.W. Rhodes

\section{Part One: Surveying the Field}

1 From Prime Ministerial Power to Core Executive R.A.W. Rhodes

2 Central Government Departments and the Policy Process

Martin J. Smith, David Marsh and David Richards

\section{Part Two: Interpreting History}

3 Relations between Prime Minister and Cabinet:

From Wilson to Thatcher

Simon James

4 The Downfall of Margaret Thatcher G.W. Jones

5 Interpreting the Rise and Fall of Margaret Thatcher: Power Dependence and the Core Executive Martin J. Smith

6 The Cabinet Office and Coordination, 1979-87 Anthony Seldon

7 The Ethos of the Cabinet Office: A Comment on the Testimony of Officials Michael Lee 
8 Ministerial Responsibility and the Theory of the British State

Alan Beattie

\section{Part Three: Empirical Studies}

9 Reinterpreting the Westland Affair: Theories of the State and Core Executive Decision Making Patrick Dunleavy

10 Core Executive Decision Making on High Technology Issues: The Case of the Alvey Report Leo Keliher

11 Joining the ERM: Analysing a Core Executive Policy Disaster

Helen Thompson

12 Leaders, Politics and Institutional Change:

The Decline of Prime Ministerial Accountability to the House of Commons, 1868-1990

Patrick Dunleavy and G.W. Jones with June Burnham, Robert Elgie and Peter Fysh

13 Estimating the Distribution of Positional Influence in Cabinet Committees under Major Patrick Dunleavy

Guide to Further Reading $\quad$ R.A.W. Rhodes

Bibliography 


\section{List of Tables}

1.1 Policy community and policy network: the Rhodes model

7.1 Postings to Cabinet Office from departments 154

10.1 Top ten companies attracting government grants from Alvey

10.2 Breakdown of funding across technical areas, 1982 to June 1987

13.1 The cabinet committee structure in May $1992 \quad 305$

13.2 Committee influence scores for senior ministers, 1992

13.3 The linkages between cabinet members created by joint membership of committees and subcommittees

13.4 The coalitional prospects for cabinet ministers $\quad 319$

13.5 Committee/main subcommittee chairs 


\section{List of Figures}

1.1 Components of core, bureau, program and super-program budgets

5.1 A model of prime ministerial power

9.1 Networks of business/governmental linkages in the Westland affair

12.1 Smoothed adjusted questions per session, 1868-1989

12.2 Smoothed adjusted statements per session, 1868-1989

12.3 Smoothed adjusted speeches per session, 1868-1989

12.4 Smoothed adjusted debating interventions per session, 1868-1989

12.5 Overall activism of prime ministers since $1868 \quad 293$

12.6 Overall parliamentary activism of prime ministers since 1940

13.1 Two measures of cabinet ministers' positional influence 


\section{Notes on the Contributors}

Alan Beattie is Senior Lecturer in Government at the London School of Economics and Political Science.

June Burnham is a researcher in the Department of Government at the London School of Economics and Political Science.

Patrick Dunleavy is Professor of Government at the London School of Economics and Political Science and author of Democracy, Bureaucracy and Public Choice (1991).

Robert Elgie is Lecturer in Politics in the Department of European Studies at Loughborough University and author of The Role of the Prime Minister in France, 1981-91 (1993).

Peter Fysh is a Lecturer in the Modern Languages Department at Nottingham Trent University.

Simon James is visiting fellow in Politics, University of Newcastle upon Tyne and author of British Cabinet Government (1992).

G.W. Jones is Professor of Government at the London School of Economics and Political Science and editor of West European Prime Ministers (1991).

Leo Keliher gained his docrorate at the London School of Economics and Political Science in 1987, and is now Director General of Queensland Emergency Services.

Michael Lee is Emeritus Professor of Politics at the University of Bristol.

David Marsh is Professor of Government at the University of Strathclyde and author of The New Politics of British Trade Unionism (1992).

David Richards is a research student in the Department of Government, University of Strathclyde.

R.A.W. Rhodes is Professor of Politics at the University of Newcastle upon Tyne, author of Beyond Westminster and Whitehall (1988) and editor of Public Administration.

Anthony Seldon is Senior History Master at Tonbridge School, cofounder of the Institute of Contemporary British History and joint editor of Ruling Performance (1987).

Martin J. Smith is Lecturer in Politics at the University of Sheffield and author of Pressure, Power and Policy (1993). 
Helen Thompson gained her doctorate at the London School of Economics and Political Science in 1994, and is now Assistant Lecturer in Politics, University of Cambridge and Fellow at Clare College, Cambridge. 